\title{
Of Beads and Beaded Artistry: A Paradigmatic Study of the Beadworks of David Herbert Dale
}

\author{
Eyitayo Tolulope Ijisakin \\ Department of Fine and Applied Arts, \\ Obafemi Awolowo University, \\ Ile-Ife, Nigeria
}

DOI: https://doi.org/10.36941/ajis-2020-0o86

\begin{abstract}
Beads have played important roles as personal adornment, in the paraphernalia of royalty of African kings, in commerce, religious activities, and traditional medicines among others. Previous studies on beads have focused mainly on its use in antiquity, while scholarships on how visual artists have engaged beads in creating works of art in contemporary times are scanty. This study therefore focuses on the beadworks of David Dale with a view to examining how the artist has ingeniously engaged beads as a means of creative expression. Data for the study were derived from field investigation through oral interviews with David Dale and art connoisseurs. Secondary data were sourced from relevant literature. Forms and stylistic inclinations were used to aid in-depth understanding of the content of the beadworks. Data collected were treated with the descriptive approach of art historical study. The findings of the study revealed that Dale's beadworks are highly naturalistic, with perfect composition and great varieties of subject matter that focus on the contemporary cosmopolitan genre. The study concludes that beads which have been one of the most significant aspects of sub-Saharan material culture for ages have been ingeniously explored by Dale in creating enthralling works of art.
\end{abstract}

Keywords: Bead, Beadwork, African art, Africa, David Dale, Antiquity, Glassmaking industry, Art history, Material culture

\section{Introduction}

Beads are small, often spherical objects, made of clay, glass, paper, plastic, wood, or other suitable materials. Beads come in different colours, usually perforated for a string to connect one with a lot of others; they are usually used in making pieces of jewellery. Bead is a derivative of the Middle English word, bede, and Old English gebed, which were originally referred to as "a prayer", prayer beads, or rosaries (Catholic Encyclopedia, 2019). The Yoruba of Nigeria broadly refer to all red beads as iyùn, while the blue beads are called sègi. Other names for beads are ilèkè, kele, èrinlà, ikàn, àkún, séséefun, and lágídígba. Beads have been among the most important elements of sub-Saharan material culture

\footnotetext{
${ }^{1}$ Kele is an alternating red and white bead, devoted symbols used by traditional worshipers of Sàngó (Yoruba god of thunder) and Oya, his wife. This underscores the Yoruba maxim "ilèkè po l'oja ki Sàngó to wo mo kele", meaning that despite abundant availability of beads in the market, Sàngó is very fond of kele with which he has an inseparable connection. The white of kele provides a calming effect on the on the hot temperament of Sàngó.
} 
for millennia; they have been used on important occasions and in the royal life of African kings. Beads featured prominently in religious activities, traditional medicines, as currency, and as a medium of artistic expression.

Beads are highly treasured in cultures across Africa, it is one of the greatest symbols of prosperity and blessings, it also has intimate connection with royalty and spirituality. Among the Yoruba, it is a general belief that àkún is connected with initiation into different age groups, or that the wearer belongs to the Council of Elders known as Ògbóni Cult (Adeyela, 2009) ${ }^{2}$. Bead as one of the earliest known forms of artistic expression were used in human body beautification such as the perforated shell beads of Blombos caves in South Africa (Jacobs, Duller, Wintle, \& Henshilwood, 2006). Beads of different sizes made from ostrich eggshells have also served to distinguish cultural traits. For instance, large ostrich eggshell beads associated with herders' sites during the last 2000 years, have been used to determine relationships between the hunter-gatherers and the pastoralists of southwestern Cape in South Africa (Yates \& Smith, 1993; Smith, Sadr, Gribble, \& Yates, 1991). According to Ambrose (1998), the !Kung of the Kalahari used beads made from ostrich eggshell in exchange for food during famine.

In the early $15^{\text {th }}$ century, glass beads were used in trade by barter by Portuguese traders along the West African coast. In North America, beads and assorted trinkets were used infamously by Peter Minuit ${ }^{3}$ to buy Manhattan Island from the Lenape Indians (Encyclopedia of World Biography, 2004). Beads were part of the springboards that pivoted early globalization as glass beads were massively brought into Africa from Europe. This importation of beads was so astonishing that it was referred to as "the Bead rush" (Kaufmann, 1993). Ijisakin (2012) argues that glass beads were well-known in the $19^{\text {th }}$ century trade; and in spite of the substantial evidence ${ }^{4}$ of extensive production of beads and its usage in the pre-historic Africa, beads became more prominent on the continent consequent to contact with the European and Mediterranean traders.

In many cultures across Africa, beads are often embedded with proverbs and symbolic visual languages to communicate messages between two or more people. The colours of beads and their designs are used to pass across messages about gender, age, and characteristics of the wearers/holders of the beadworks. Oral traditions are interpreted into visuals in different forms which include the use of beads; for instance, the people of Zulu and Xhosa in South Africa, and the East African nomadic people of Masai have produced awe-inspiring beadworks (The Museum Rietberg, 2018).

In Nigeria, the making of beads is an ancient craft among the various ethnic groups. For instance, Olokun ${ }^{5}$ is known for her expansive bead making industry at Igbo-Olokun in the ancient city of Ile-Ife. Extensive usage of beads is also evident in the Ife naturalistic bronze figures, Benin bronze works, stone images of Esie, as well as glass and metal works of Bida. Some Nok terra cottas also depict human figures with beads at the necks, wrists, and ankles. Further, beads of all kinds excavated from graveyards of ancient rulers and traditional priests at Igbo-Ukwu in the 1960s attests to elaborate use of bead in Nigeria (Ijisakin, 2011). The richness of royal families of Owo and Benin people in southern Nigeria is evident in their use of rare and exotic beads. In addition, bèbè and lágídigba popular as waist beads among Yoruba women are explicitly erotic, as they are attractive and capable of evoking profound emotional responses.

\footnotetext{
${ }^{2}$ Adeyela, Aibatu (79) Beads seller, No. 62, Iremo Road, Ile-Ife. Personal interview with the author to seek information on various types of beads and their uses. Tuesday, March 10, 2009

${ }^{3}$ Peter Minuit (b. 1580 - d. 1638), a Dutch colonial administrator of the New Amsterdam renowned for buying Manhattan Island from the Indians with trade goods worth a meager 6o guilders. See more details in the Encyclopedia of World Biography (2004).

${ }^{4}$ See Eluyemi, (1975, 1976); Fagg, (1980); Euba, (1982); Drewal, Pemberton, E Abiodun (1989); Drewal and Mason (1998); Simak, Dreibelbis, E Dubin (2010) for more details on production of beads and its usage in Africa.

${ }^{5}$ Olokun was the Queen of Oduduwa, the progenitor of Yoruba race.
} 
Beads have been used to explore the unsung creativity of the womenfolk, to establish power, authority, spirituality, and importance of the individual(s), or association with a particular group in the society. The auspicious qualities of beads and its historical antecedents perhaps remain one of the reasons why many artists have chosen beads as a medium of expression (Gittlen, 2018). As a means of expressing creative ideas, Jimoh Buraimoh for instance, is renowned as the first to explore the use of beads among contemporary artists in Nigeria. Buraimoh, whose works dwell on the philosophy of African people, drew so much inspiration from the Yoruba tradition of using beads to embellish ceremonial fabrics, crowns, and other paraphernalia of royalty (Ijisakin, 2012). Other artists who have explored creative usage of beads include Rufus Ogundele, Nike Okundaye, David Osevwe, Eyitayo Ijisakin, Yinka Adeyemi, Peter Coker, Felix Ekeada, Chuka Amaefuna, Dola Daramola and David Dale.

David Dale has experimented with, and mastered over twenty-three media of visual art, his collection of beadworks provided the impetus for this research. This study, therefore, focuses on the beadworks of David Dale with a view to examining how he has innovatively engaged the beads as a means of creative expression. The study provides an overview of African beadworks through the lens of relevant literature; it investigates artistic development of David Dale; and examines the forms and techniques in his beadworks.

\section{An Overview of African Beadworks: A Review of Literature}

There exists a number of studies on African beads and its usage, for instance Simak et al. (2010) in African Beads: Jewel of a Continent, offers a general survey of African beads, with an explanation on the materials, types, styles, as well as the history of bead making in Africa. Alagoa (1985) argues that the Portuguese merchants traded beads for gold at Elmina, for copper manillas in the Congo, and as currency in the Niger-Delta. Maghrib merchants also traded beads with copper, and wool, in exchange for gold in Tukrur. In Egypt, beads were part of the treasured objects discovered in the early bronze-age tombs and graveyards. According to Saitowitz (1993), a large-scale glass production factory which used assorted materials such as glass, gold, chalcedony, and pearls flourished in Egypt during the eighteenth dynasty between 1559 and 1531 BC.

The Zulu, Masai, Bambara, Ndebele, peoples of the Cameroun grasslands, the Samburu, Nupe, Fulani Agoi, and Yoruba are known for their rich traditions of creative use of beads (Ijisakin, 2011). Drewal and Mason (1998) argue that African beadwork could be described as an important symbol that represents unique individuality, spirituality, social status, royalty, as well as authority. In South Africa, Schoeman (1996) observes that prior to the colonial era; the people of KwaZulu-Natal and Eastern Provinces in South Africa produced vibrant and exciting beadworks in which eloquent romantic messages between opposite sex were woven into its design. The true beauty of traditional Zulu beadwork lies in the understanding of how they effectively integrate social values into their beadworks. The Zulu beadwork is a form of eloquent language, specially designed to impress the opposite sex. Schoeman (1996) further argues that traditional Zulu beadwork is

"...far more than a merely decorative art of weaving small glass beads into aesthetically pleasing patterns...these designs were a surprisingly articulate vehicle of communication that helped to regulate behaviour between individuals of opposite gender."

Studies have shown evidence of beads and bead making furnaces in Olokun grove, Ile-Ife (Eluyemi, 1986); and that a glass bead making industry dated between 11th and 14th century A.D. flourished at Ayelabowo in Ile-Ife (Euba, 1982). Sheba (2001) argues that the Yoruba people used beads in àrokò (coded message) as a form of conveying symbolic messages. Further, the crowns of the Yoruba kings constitute a sizable number of the most spectacular beaded objects in Africa; these crowns are worn by the rulers of the Yoruba people with veils during public functions. The veil, made of beaded strands is meant for shrouding the king's face. According to the ancient traditions, strands of beads were regarded as emblems of the gods; such that it is among the most effective symbol of 
their kingship. Falola \& Adejumobi (2004) observe that the beaded crown with veils is embedded with so much information that could be used to study and understand the philosophy behind art and authority among the Yoruba. Crabtree and Stallebrass (2002) further expound on the importance of Ile-Ife as the cradle city for all other Yoruba towns whose rulers have the privilege to wear beaded crowns. The legendary Arè (beaded crown) of the Oòni of Ifè authenticates the King's status as the paramount ruler of the entire Yoruba race at home and in diasporas.

On the whole, much of the previous studies have focused on bead production and their uses in antiquity, in commerce as a medium of exchange, in body decoration, in royalty, and as a medium of communication among others. However, studies on how visual artists have engaged with beads in pushing the medium in new directions are scanty. This study, therefore, examines how David Dale has employed beads in creating enthralling works of art.

\section{Methodology}

Data for this study were derived through field investigation; oral interviews were conducted with David Dale and collectors of his beadworks. Data collected helped in contextualizing the beadworks, while artistic development of Dale served as a point of reference for better understanding of his collection of works. Photographs were also used for critical appraisal of the forms of the beadworks. Secondary data were sourced from relevant literature. Data collected were analysed using the descriptive method of art historical study.

\section{The Artistic Development of David Dale}

David Herbert Dale (Plate 1) was born into the family of Mr. and Mrs. Charles Ernest Dale on November 22, 1947, in Kano, northern part of Nigeria. His father was from Kent, in England, while his mother was an Itshekiri woman from Warri, Delta State, Nigeria. Before the age of three, Dale lived with Johanna Ernest (his aunt) in Burrswood, Kent, England. Dale started laying a solid foundation towards building a reputation as an international artist from an early age. As early as age seven, little Dale was paid three guinea for each one of his two works, titled: "the Apple Seller" and "Cart Pushers". These are two pen drawings which were published in the "Liverpool Children's Echo", the children section of a Liverpool newspaper. At the age of twelve, he was one of the winners in the "Good Life Painting Contest" at Kingsway in Lagos. He also won the second prize in the "MacintoshToffee Competition" in Lagos; all these led to the frequent publishing of his works in the Liverpool Magazine, in England. Dale had his elementary education at the public school in Groombridge, Kent, England (1951-1960). He was at Guildford Grammar School, Surrey, England between 1961 and 1963.

Consequent to the death of his father in 1963, Dale returned to Nigeria to complete his secondary school education at Saint Gregory's College, Obalende, Lagos. It was at Saint Gregory's College that Dale met the renowned master printmaker, Bruce Onobrakpeya, who was Dale's teacher. Dale obtained A1 grade in Fine Arts to the delight of his school principal, Reverend Father MacCarthy, who Dale has promised never to let the school down. Dale worked briefly with the Federal Ministry of Communication, Lagos, between January and July 1967; he designed the Ministry's logo and its 1967 Christmas card. In 1967, he gained admission to study Fine Arts at the Ahmadu Bello University, Zaria.

Dale was employed by City Group as Advertising Manager in 1971. By 1974, Dale started creative experimentation with beads when the founder of the City Group, Chief Adebayo Adeleke inspired him to produce artworks using beads. Consequently, he produced his first beadwork "City Group, Peacock" (Plate 2). Dale later worked with Kofo Bucknor Akerele as the Art Director in Akrel Advertising Limited, Lagos, between 1977 and 1984. He taught Visual Communication as a part-time lecturer in the Department of Architecture, University of Lagos; and started as a full-time studio artist in 1984 . 
Dale participated in the Ori-Olokun Art Workshop in the University of Ife, (now Obafemi Awolowo University) on the invitation of Ulli Beier. Dale was appointed as the graphic consultant to the African Architectural Technology Exhibition during the iconic World Black and African cultural event known as Festival of Arts and Culture (FESTAC '77), held in Lagos between 15 January, and 12 February 1977. Dale featured in the "NUCLEUS", maiden exhibition of art collections in Nigeria's National Gallery of Modern Art (1981). Dale was also one of the selected nine accomplished artists that featured in the art exhibition known as the "Living Masters" between February 23 and March 9, 2007 .

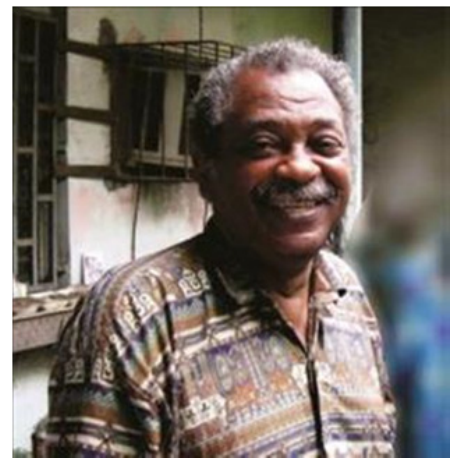

Plate 1: David Dale

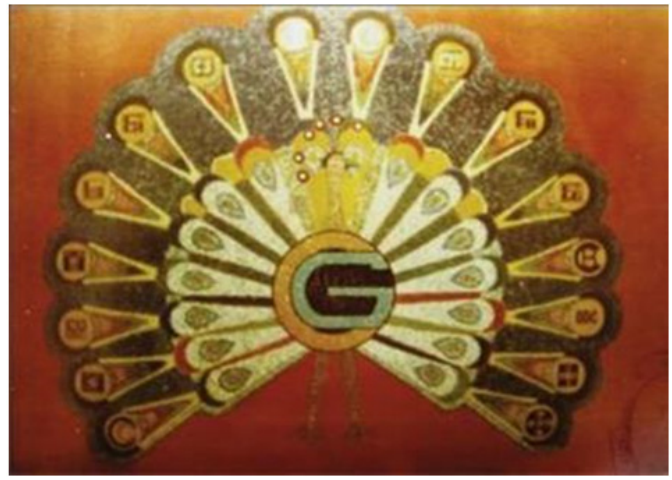

Plate 2: City Group (Peacock) (244 x 336 cm); David Dale, 1974

Dale has taken part in over 70 solo and group art exhibitions both at home and abroad, between 1972 to date. His first solo exhibition held in October 1972 was hosted by Mr. and Mrs. Frank AigImoukhuede in Ikoyi, Lagos. Others include "Operation PUSH Expo" held in Chicago in 1972; "Deep Etchings" at Ori Olokun Cultural Centre, Ile-Ife, 1973; "Modern African Art" held at Everson Museum of Art in Syracuse, New York, 1973; "Nigerian Traditional and Contemporary Art" in Bucharest, Romania, 1976; "FESTAC '77"; "Exhibition of Nigerian Contemporary Art", held in Dakar, Senegal, 1980; "the Nucleus" Lagos, 1981; "Ausstellung Nigerianische Kunst der Gegenwart:, Bonn, West Germany, 1982; "Silver Jubilee National Art Exhibition" held at National Theatre, Lagos, and Lugard Hall, Kaduna, 1985. Dale also participated in "Art for VIPs", British Caledonian VIP Lounge, Gatwick Airport, London, 1985; "Sinsemilla Art Expo", Sheraton Hotel, Lagos, 1986; "First Masters Art Exhibition”, Lagos 1987, and, 1992; "the New Meets the Old”, National Museum, Lagos, 1989; "Unity through Art", National Museum, Lagos, 1990; "the Works of David H. Dale" (solo) held at the 
Nigerian Embassy, Stockholm, Sweden, 1990; the "Living Masters", Lagos, 2007; the "Update" (solo) held at the Quintessence Gallery, Ikoyi, Lagos, 2007; and "Art Expo Nigeria”, Abuja, 2008.

Dale's beadworks are held in numerous private and public collections around the world. Notable among the collectors of Dale's beadworks include Adebayo Adeleke of City Group; Engineer Yemisi Shyllon of OYASAF ${ }^{6}$; Dolapo Atekoja; Chief Ade Ojo; Remi Makanjuola; Kunle Ojora; Folabi Kofo-Abayomi; Chief Olisambu, Mike Adenuga; Rasheed Gbadamosi; Sam Olagbaju; Alani Akinrinade; Dele Jegede; Yusuf Grillo; Saburi Biobaku; Olaseinde Odimayo; Julius Nyerere; Mohammed Ali; William Ford; and Jack Schellingberger. Others include the Federal Department of Culture and Archives, Lagos; the National Museum, Lagos; the Nigerian Stock Exchange; Mydrim Gallery; Gong Gallery; Quintessence Gallery; Shell International; Toyota in Japan; the Bradford Museum, United Kingdom; Howard University; Ford Foundation; Mbari Art, Washinton D.C.; and Boston Museum of Arts, Boston in the United States of America.

Dale is a recipient of several awards and honours including the First Class Star Award for outstanding contributions to contemporary art in Africa sponsored by the Humane Education Institute of Africa, Dar-es-Salam, Tanzania. Dale received the International Graphic Triennale (Intergrafik '87) award in East Germany, 1987. He also won a bronze medal for his contribution to art in Nigeria, by the Diamond Publication, Nigeria (1992); the Solidra Circle Award; as well as Professor Ade Ajayi's Judeas Trust Award for Creativity, both in November 2001. Dale was the 2003 "Man of the Year" of the American Biographical Institute, USA. He is listed in many "Who is Who" among which are the "Contemporary American Who is Who" published by the American Biographical Institute; "Contemporary British Who is Who", published by the International Biographical Institute, England; and the "Nigerian Artists: a Who is Who and Bibliography" published by the Smithsonian Institution Libraries, London. Dale was a complete gentleman, an extrovert, and a great philanthropist who gave succor to the needy at the expense of his own needs. He advised that the budding artists should strive at creative excellence, rather than making financial gains their watchword. Dale holds Pablo Picasso, Akinola Lasekan, and Bruce Onobrakpeya in high esteem for their lofty contributions to the development of art and artists. He passed away in Lagos, Nigeria, on Tuesday, August 6, 2019.

\section{Forms and Techniques of the Beadworks of David Dale}

Forms are the particular way that something is or appears to be; it is the structure, design, or arrangement of a work of art. In the production of works of art, the artist works on expression, sentiments, emotions, and ideas derived through interactions with society. The unique genius of the artist lies in his sensitivity to the social and cultural milieu, and in the ability to respond in an aesthetically satisfying medium. According to Folarin (2001), artists like scientists, are in endless search of truth, beginning with a close study of nature, the artist proceeds to record his observations, a leaf, an insect, a bird, the changing clouds, the intricacies of human anatomy, or a light falling upon a drapery. The extent to which the hand and mind combine information with beauty describes the immeasurable magic of artistic experimentation and communication. It is in light of this that David Dale considers his immediate environment when executing his beadworks. Dale also draws inspirations from meditation, dreams, travelling, doodling, and interaction with people.

The forms of beadworks of Dale can be described as realistic and naturalistic. Realism and naturalism are used to give a detailed description of how close objects in works of art bear

\footnotetext{
${ }^{6}$ OYASAF (Omoba Yemisi Adedoyin Shyllon Art Foundation) was established in 2007 as a non-for-profit organization with the aim of promoting the appreciation and study of Nigerian visual arts, artists, and culture. OYASAF makes its collection available to global audience; it is a focal point for museums, educational institutions, scholars, critics, art curators, artists, and culture enthusiasts. OYASAF prides itself as the custodian of the largest collection of contemporary works of art in Nigeria, with over 70oo works, and more than 55, ooo photographs that narrate Nigeria's cultural heritage.
} 
resemblance with those seen in everyday life. Though closely related, the terms are not interchangeable, while realism is a whole rendition of actual appearance, naturalism renders object as they might exist, such that could involve some improvements to actual appearance. Further, a lot of illusionism is used in the beadworks of Dale; this is with a view to creating three-dimensional space on a two-dimensional plane. To create the effect of illusionism in the beadworks, Dale's compositions are usually made of overlapping shapes, light to dark shading, and full linear perspective as evident in "Family Unit" (Plate 3).

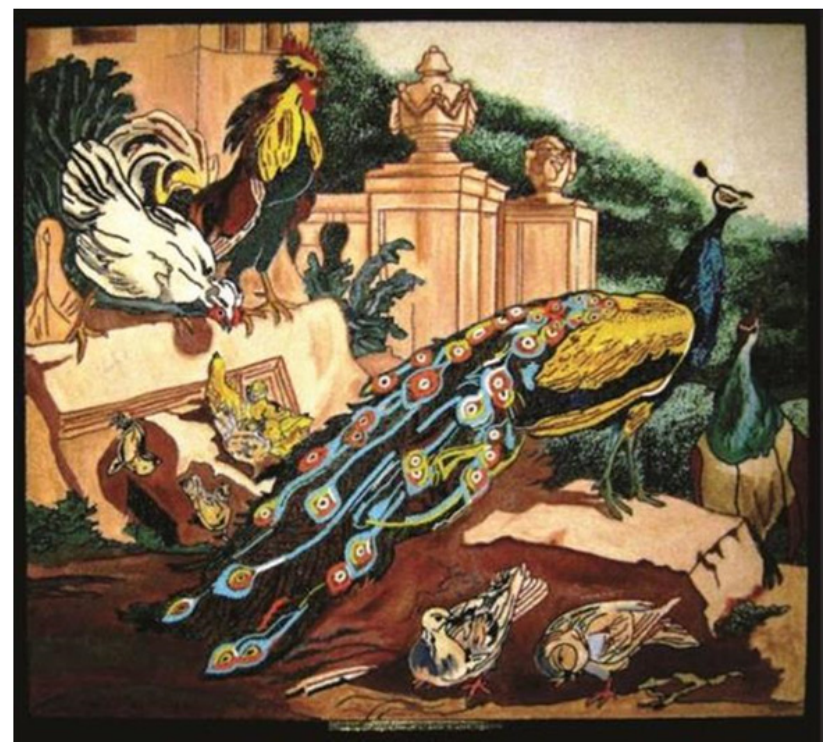

Plate 3: Family Units (105 x 117 cm); David Dale, 1998

On the technique of executing his beadworks, Dale is an experimentalist who has mastered and produced magnificent art pieces in over twenty-three artistic media ${ }^{7}$. Dale has a kind of prodigal talent with which he experiments before producing his beadworks, his works are visually appealing and intellectually challenging. Dale would first string his beads using a stick of broom, and then delineates his composition before filling it up with beads. The beads come in different sizes and colours, and these play a significant role in the overall quality of the work. Dale adds Turari (frankincense) into the linseed oil with which he mixes his oil colour in other to achieve a longlasting luster on the part of his beadwork where he may want to paint with oil colour. Dale prefers to use high-quality beads which are adhered to the board with the use of Araldite.

Dale is not confined to a particular shape; he produces works from rectangular to very slim rectangular, as well as square shapes. His works could also be in portrait or landscape format. His works range from the very small 33 by 61 centimeters "Step by Step", (Plate 4); to the massive 620 by 1,030 centimeters "As the Evening Falls". He uses beads of different colours to create a unifying force, and he often mixes linseed oil with oil colour to paint on the section where the exact colour of beads is not readily available. He also uses crushed beads to achieve special effects in his beadworks. In the

${ }^{7}$ Artistic media in which Dale's mastery is clearly evident include beadwork, mosaic, stained glass, etching, gilded engraving, lino cut, wood cut, water colour, pen and ink, oil colour, serigraphy, collage, ceramic, gouache, air brush work, fresco, metal work, veneer, charcoal, and pastel. 
observation of Filani (2007), the tonal splendour of Dale's graphically illustrative beadworks reveals the grandeur of his varied talent and assiduous skills.

Dale's beadworks are highly naturalistic, with perfect composition and great varieties of subject matter which focus on the contemporary cosmopolitan genre ranging from nature ("Eclipse" Plate 5 , and "Sunset" Plate 6), to landscape (Plate 6), and compositions of human activities ("At the Well" Plate 7, and "Dignity of Labour" Plate 8). His formalistic language is clear and unambiguous; this explains why his visual expressions have attracted a large community of art lovers across the globe. His beadworks are sourced from photographs, others from his sketchpad and imaginative composition. Good draughtsmanship and meticulous finishing as evident in "Family Units" (Plate 3) and "Motherhood" (Plate 9) also characterize his creative adventures. One could easily deduce that Dale's beadworks fall within the group of contemporary artists which Adepegba (1995) describes as those whose works show "discernible images of experiences and ideas". The selection of Dale's accomplishment as enumerated by Kelly and Stanley (1993) give credence to the influential position of Dale in the contemporary art of Nigeria.

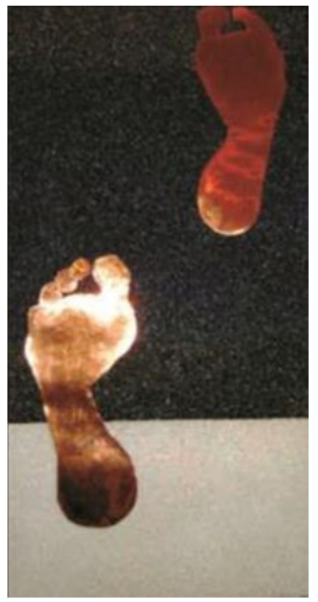

Plate 4: Step by Step (33 x 61 cm); David Dale, 2010

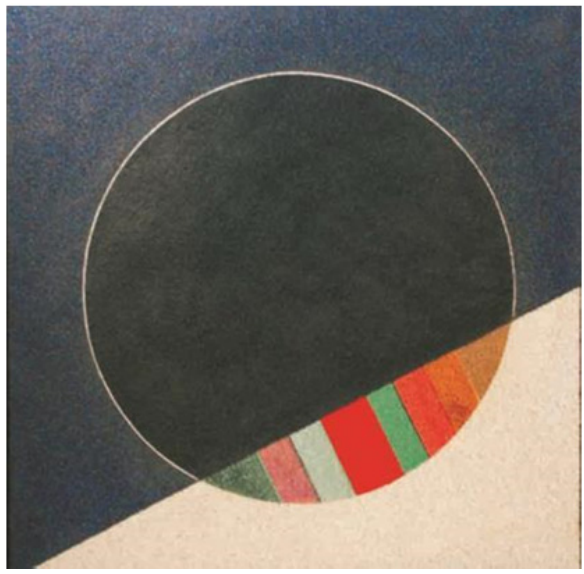

Plate 5: Eclipse; David Dale, 2008 


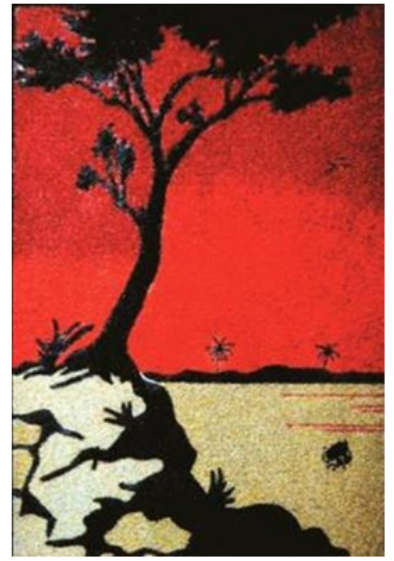

Plate 6: Sunset (58 x $92 \mathrm{~cm})$; David Dale

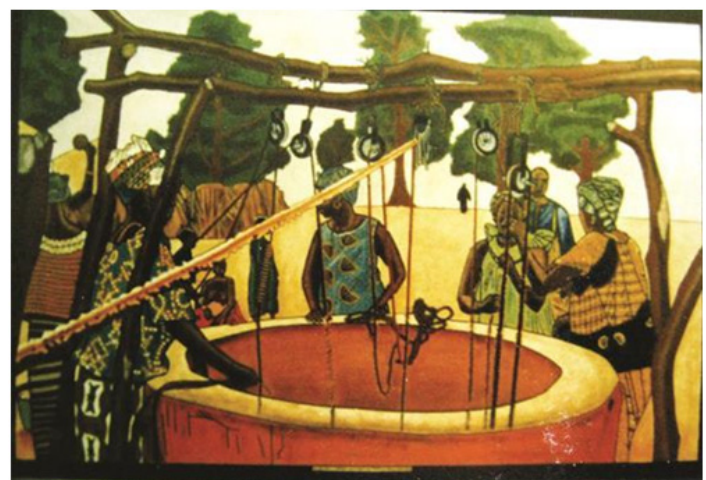

Plate 7: At the Well (42 x 54 cm); David Dale, 1993

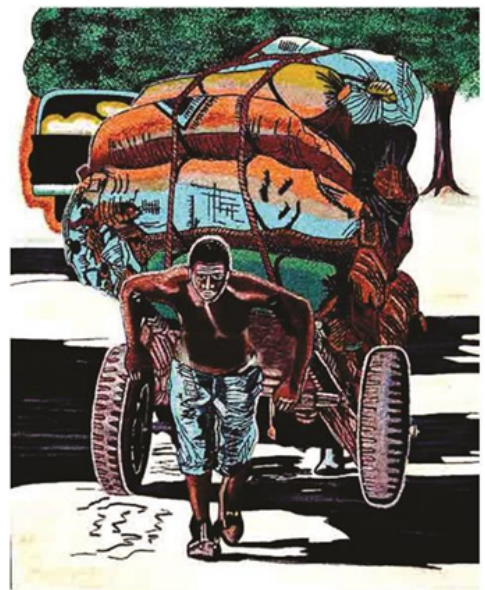

Plate 8: Dignity of Labour (120 x 170); David Dale, 1994 


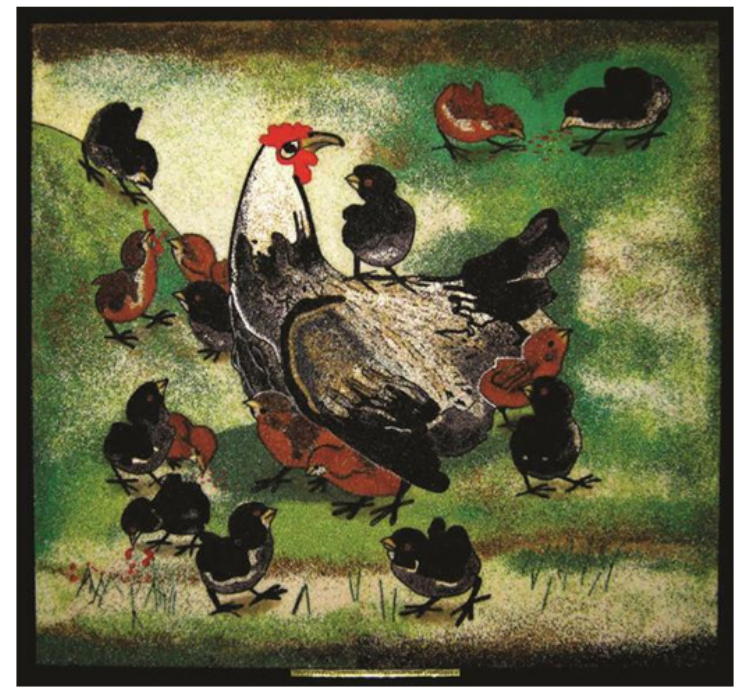

Plate 9: Motherhood (122 x $130 \mathrm{~cm}$ ); David Dale, 2005

\section{Conclusion}

Beads have played very crucial roles in different cultures since the days of yore. The beads have also been explored by David Dale in creating enthralling works of art. The dexterity of Dale in diverse media exemplifies the hallmark of elegance that characterized his beadworks. There is a high level of intellectualism in the beadworks of Dale. The compositions of subjects in his beadworks are generally interpreted in simple, and easy to understand manner, with astonishing use of space. His works show good understanding and usage of the elements and principles of design. Little wonder that Oloidi (2007) argues that Dale is a celebrated hero to the crème de la crème of Nigerian art connoisseurs, to art colleagues, and budding artists. His visual language is unambiguous and so impressive that it has drawn the attention of a large community of art connoisseurs around the world.

\section{Acknowledgement}

The author is grateful to David Dale whose beadworks provided the impetus for this study; Dale gave his time in a pleasant and very conducive atmosphere during the interview. The author is also grateful to Prof. Ruth Simbao, SARChI Chair in Geopolitics and the Arts of Africa, Rhodes University, in South Africa, from whose pool of intellectual wealth and kindness the author has benefited as a postdoctoral research fellow.

\section{References}

Adepegba, Cornelius O. (1995): Nigerian Art: Its Traditions and Modern Tendencies. Ibadan: Jodad Publishers. Alagoa, E. J. (1985): “The Niger Delta States and Their Neighbours to c. 18oo”, in J.F. Ade Ajayi and Michael Crowther (eds.) History of West Africa, Vol. 1, third edition, Lagos: Longman Group Ltd. p. 398.

Ambrose S. H. (1998). Chronology of the Later Stone Age and food production in East Africa. Journal of Archaeological Science 25:377-392 http://in-africa.org/wp-content/uploads/2012/12/Ambrose-1998-JAS-LSAchronology-East-Africa.pdf

Catholic Encyclopedia (2019). "Bede" Catholic Online Retrieved August 21, 2019, from https://www.catholic.org/encyclopedia/view.php?id=1640

Crabtree, Caroline and Pam Stallebrass (2002): Beadwork: A World Guide, London: Thames \& Hudson Ltd. 
Drewal, Henry John and John Mason (1998): Beads, Body and Soul: Art and Light in the Yoruba Universe. Los Angeles: UCLA Fowler Museum of Cultural History.

Drewal, Henry John, John Pemberton III, and Rowland Abiodun (1989): Yoruba: Nine Centuries of Africa Art and Thought. New York: the Centre for African Art in association with Harry N. Abrams Inc., Publishers.

Eluyemi, Omotoso (1975): New Terracotta Finds at Oke-Eso, Ife, African Arts, Vol. IX (1). pp. 32-33.

Eluyemi, Omotoso (1976): "Ife Traditional Art and Craft Industries: investigation into their origin and development" in Akinjogbin I. A. and Ekemode G. O. (eds.) The Proceedings of the Conference on Yoruba Civilization.

Eluyemi, Omotoso (1986): This is Ile-Ife. Ile-Ife: Adesanmi Printing Works.

Encyclopedia of World Biography (2004). Peter Minuit. Detroit: the Gale Group Inc. Retrieved August 10, 2019, from https://www.encyclopedia.com/history/encyclopedias-almanacs-transcripts-and-maps/peter-minuit

Euba, O. (1982): "Of Blue Beads and Red: The Role of Ife in the West African Trade in Kori Beads", Journal of Historical Society of Nigeria, Volume II, Nos. 1 and 2. Dec. 1981 - Jan. 1982. pp. 115- 120

Fagg, W. (1980), Yoruba Beadwork: Art of Nigeria. New York: Rizolli.

Falola, Toyin and Saheed A. Adejumobi (2004): "Iron Smiting and Jewelry Making”, in Lawal, N. S., Sadiku, M. N. O. and Dopamu, P. A. (eds.) Understanding Yoruba Life and Culture. Eritrea: Africa World Press, Inc.

Filani, Kunle (2007): "Mastering the Society through Art: The Legacy of the Living Masters", Living Masters: an Exhibition Catalogue, held on February 23- March 2007, Guaranty Trust Bank Plc.

Folarin, A. (2001). "The Importance of Creative Experimentation”, Inaugural Lecture Series 152; Ile-Ife: Obafemi Awolowo University Press.

Gittlen, Ariela (2018). Artists Turning Beads into Spellbinding Works of Art. Retrieved August 10, 2019, from https://www.artsy.net/article/artsy-editorial-6-artists-turning-beads-spellbinding-works-art

Ijisakin E. T. (2012): "Afro-Cultural Imperatives in the Bead Paintings of Jimoh Buraimoh"; The African Symposium: Journal of the African Educational Research Network, <http://www.ncsu.edu/aern/TAS12.1/TAS12.1.htm> Virginia Union University, U.S.A. Vol. 12, No. 1, pp.29-45.

Ijisakin, E. T. (2011): "The Beadworks of Jimoh Buraimoh and David Dale" an M.Phil Thesis of the Department of Fine and Applied Arts, Obafemi Awolowo University, Ile-Ife.

Jacobs Z, Duller GA, Wintle AG, Henshilwood CS (2006). Extending the chronology of deposits at Blombos Cave, South Africa, back to $140 \mathrm{ka}$ using optical dating of single and multiple grains of quartz. Journal of Human Evolution 51(3):255-73.

Kaufmann, C. (1993): "The Bead Rush: Development of the 19th Century Bead Trade from Cape Town to King William's Town”, Ezakwantu: Beadwork from the Eastern Cape, Cape Town. South African National Gallery.

Kelly, Bernice M. and Janet L. Stanley (1993): Nigerian Artists: a Who's Who and Bibliography, Smithsonian Institution Libraries, Hans Zell Publishers, London, New York, Melbourne, Munich.

Saitowitz, S. (1993): “Towards a History of Glass Beads", Ezakwantu: Beadwork from the Eastern Cape, Cape Town. South African National Gallery.

Oloidi, O. (2007): Modern Nigerian Art: a Celebration of Selected Mastersll, Living Masters: an exhibition of the works Abayomi Barber, Bisi Fakeye, Bruce Onobrakpeya, David Dale, El Anatsui, Isiaka Osunde, Kolade Osinowo, Muraina Oyelami, and Yusuf Grillo; held on February 23-March 9, organized by Mydrim Gallery and Guaranty Trust Bank Plc.

Sheba, Eben (2001): “The Symbolism of Àrokò and Ààlè in Yorùbá Tradition”, the Nigerian Field. Vol. 66, Part 2. p. 137.

Simak, E., Dreibelbis, C., and Dubin, L. S., (2010). African Beads: Jewels of a Continent. Africa Direct

Smith, A. B., Sadr, K., Gribble, J., \& Yates, R. (1991). 'Excavations in the south-western Cape, South Africa, and the archaeological identity of prehistoric hunter-gatherers within the last 2000 years' South African Archaeological Bulletin, 46:71-91

Schoeman, H. Stan (1996). Eloquent Elegance: Beadwork in the ZULU cultural tradition Retrieved August 22, 2019 from https://www.oerafrica.org/FTPFolder/guyana/CCTI\%20CD/CCTI\%20CD/findinginformation/content/documents /zulu\%2obeadwork\%2ohome\%2opage.htm

The Museum Rietberg (2018). Bead Art from Africa: the Motta's Collection (Ed. Michaela Oberhofer). An art exhibition of beadworks from South Africa and other regions in Africa, shown at the Museum Rietberg in connection with the Zurich Festival 2018 from 7 June to 21 October 2018. Retrieved August 10, 2019 from https://rietberg.ch/files/Presse/Pressemitteilungen/EN/2018_6_e_mm_perlkunst_gesamt.pdf

Yates, R. \& Smith, A. B. (1993). 'Ideology and hunter/herder archaeology in the South Western Cape' Southern African Field Archaeology, 2:96-104 